\title{
Biased sex-ratio in woodland grouse population of the Tatra National Park, suggested by molecular sexing of non-invasive samples
}

\author{
Anna SANTOREK ${ }^{1}$, Tomasz ZWIJACZ-KOZICA ${ }^{2}$, Beata DulisZ ${ }^{3}$, Dorota MERTA ${ }^{4}$ \\ and Robert RUTKOWSKI ${ }^{1}$ \\ ${ }^{1}$ Museum and Institute of Zoology, Polish Academy of Sciences, Wilcza 64, 00-679 Warszawa, Poland \\ ${ }^{2}$ Tatra National Park, Kuźnice 1, 34-500 Zakopane, Poland \\ ${ }^{3}$ Faculty of Biology and Biotechnology, University of Warmia and Mazury in Olsztyn, \\ Plac Eódzki 3, Olsztyn 10-727, Poland \\ ${ }^{4}$ Department of Ecology and Environmental Protection, Pedagogical University of Kraków, \\ Podbrzezie 3, 31-054, Kraków, Poland \\ *Corresponding author email: robertrut@miiz.waw.pl
}

\begin{abstract}
Sex ratio (ratio between the number of male and female individuals in a population) is an important factor contributing to the survival rates of the population in wild. Imbalanced sex ratio is often the cause of diminished survival rates of endangered species. The analysis of DNA collected through noninvasive methodologies effectively allows to monitor populations of rare species or species that are difficult to observe in the wild. Such method was used to determine the sex ratio in populations of the capercaillie (Tetrao urogallus) and black grouse (Lyrurus tetrix) in the Tatra National Park. We collected over 250 samples (mostly excrement) in the area of the Tatra National Park and identified species via microsatellite genotyping and determined the sex using fragments of the CHD gene. We found that the majority of the samples belonged to male specimens irrespective of the species suggesting a large deviation from an equal sex ratio in wild populations of capercaillie and black grouse in the Tatra National Park. Our results point out the fundamental contribution of genetic assessment of sex ration to monitor the viability of both species in the Tatra National Park
\end{abstract}

Key words: Tetrao urogallus, Lyrurus tetrix, sex ratio, genetic sexing, non-invasive sampling

\section{INTRODUCTION}

The relative proportion of male to female individuals within a population, the sex-ratio, is one of the most important topics in population ecology (Hardy 2002). The ratio of males and females at conception, at birth and adulthood (defined as primary, secondary and adult sex ratios) has a significant influence on behaviour of individuals and the viability and even survival of the population. According to Fisher (1930), the sex ratio of a viable population should be around $1: 1$. However, the exact proportion in the cohort of breeding adults depends on several processes, e.g. sex-dependent differences in mortality at birth, sexual maturity, sex-biased and dispersal (Bessa-Gomes et al. 2004). Such processes often result in a significant variation of the relative male and female proportion at the local scale, although these differences may be counterbalancing at the meta-population level. In many species the secondary sex ratio might substantially deviates from a 1:1 ratio. For example, raising male or female offspring might involve differential costs or benefits in parental care (West 2009). In addition social, environmental, genetic and physiological factors all contributes to the gender structure of a population (Navara 2018a). Females might also be able to influence the sex of their offspring at birth (Trivers \& Willard 1973, West 2002, Pryke \& Rollins 2012). For example, Clout et al. (2002), in an attempt to enhance captive breeding of the polygynous kakapo (Strigops habroptila), was able to skew the sex ration towards males through intensive feeding of adult females. When environmental conditions are favourable, females produce more males, and rising them requires more energy. With moderate food resources, females produce offspring in a 1:1 
ratio (Robertson et al. 2006). Thus, environmental conditions might affect the sex ratio of a population, which may be of the utmost importance in the case of protected species. Both the mating system and the sex ratio influence the demography and extinction risk of a population (Lee et al. 2011, Navara 2018b). An unequal sex-ratio of the adult cohort might lead to a reduction of the effective population size and consequently decrease the viability of the population (Donald 2007). For example, Lambertucci et al. (2013) suggested that the sex-ratio of released the Andean condor (Vultur gryphus) significantly affected the effectiveness of reintroduction and reinforcement programmes.

The sex ratio of a population is often difficult to assess if based only on observational methods. Many bird species show low level of sexual dimorphism, which makes it difficult or even impossible to determine their sex based on morphology. Determining the sex of the chicks is always problematic even in species with adult sexual dimorphism, as features of the sexually dimorphic plumage do not become apparent until sexual maturity. Furthermore, even with pronounced dimorphism in adult birds, the behaviour of males and females might cause difficulties in assessing a true sex-ratio. Often one of the sexes is either more mobile or secretive than the other, leading to incorrect inference of the sex-ratio based solely on observational methods (Théry 1992; Vanderkist et al. 1999, Blackmore et al. 2011). The identification of the sex via genetic methods (molecular sexing) has therefore proved invaluable in the study of wild bird populations (Dubiec \& Zagalska-Neubauer 2006). PCR-based methods using sex-linked markers are commonly used for sex determination. Besides the highly conserved genes CHD1W/CHD1Z (Ellegren \& Sheldon 1997), also the genetic marker Wpcki has been successfully used for molecular sexing (Hori et al. 2000). The development of molecular methods for sex determination has thus allowed to overcome the intrinsic difficulties due to lack of clear phenotypic differentiation (Segelbacher \& Steinbrück 2001, Waits \& Paetkau 2005, Regnaut et al. 2006). Moreover, thanks to the use of genetic methods, it is now possible to determine the sex of an individual using non-invasive sampling (feathers, faeces found in the field). In combination with genotyping, molecular sexing allows the determination of sex ratio based on biological material obtained without the need to capture individuals, and is often the method of choice for endangered, elusive or low-density species. Advances in DNA extraction and DNA amplification technology make non-invasive sampling a source of extremely informative material for genetic research (Taberlet et al. 1999, Segelbacher \& Steinbrück 2001, Piggott et al. 2004, Broquet et al. 2007, Beja-Pereir et al. 2009, Baumgardt et al. 2013). The effectiveness of sex determination via DNA analysis from non-invasive sampling has been demonstrated for a variety of species and from a variety of biological material such as feathers, hair and droppings (Eggert et al. 2003, Bush et al. 2005, Fontanesi et al. 2008, Baumgardt et al. 2013, Yamashiro et al. 2017).

The aim of this study was to determine the sex ratio in wild populations of two endangered forest grouse living in the Tatra National Park: the capercaillie (Tetrao urogallus Linnaeus, 1758) and the black grouse (Lyrurus tetrix Linnaeus, 1758). Mountain forests with a low degree of fragmentation and human disturbance are an important stronghold for the forest grouse in Europe (Storch 2007). The Tatra Mountains represent an important refuge for the capercaillie and black grouse, and observations suggest a higher number of individuals than in other similar areas (Ciach 2016, Rutkowski et al. 2017a, Rutkowski et al. 2017b). In small and threatened populations, the degradation of the habitat, for example due to fragmentation, may cause significant deviations from an equal sex ratio (Helle et al. 1999, Sun et al. 2003). In polygynous species, such as the capercaillie, the risk of extinction is lowest when the adult sex ratio is biased towards females (Bessa-Gomes et al. 2004). The capercaillie and the black grouse are endangered, thus understanding the demographic and sex-ration of wild populations is fundamental for the protection of both species. 


\section{MATERIAL AND METHODS}

\section{Sample collection}

We collected 100 capercaille and 166 black grouse samples during field work conducted in 2018 and 2019. All the samples were collected via non-invasive means (261 faeces and 5 feathers). Faeces were stored in a freezer at $-22^{\circ} \mathrm{C}$ until DNA extraction, whereas feathers were kept in paper envelopes and stored in a freezer at $-4{ }^{\circ} \mathrm{C}$ until DNA extraction. Samples come from the Polish side of the Tatra Mountains protected as the Tatra National Park.

\section{Laboratory analysis}

We extracted DNA from droppings using the NucleoSpin Soil Kits (MACHEREY-NAGEL) and later GeneMATRIX Stool DNA purification Kit (Eurx), following the manufacturers' protocols. We extracted DNA from feathers using a GeneMATRIX Tissue DNA Purification Kit (Eurx) using the standard protocol of the manufacturer. The detailed procedure for DNA isolation process in order to minimise contamination is described in Rutkowski et al. (2017b) and Santorek et al. (2018).

To identify unique genotypes (thus individuals) among collected samples we conducted microsatellite genotyping of the extracted DNA using multiplex PCR. We amplified 8 microsatellite loci: TuT1, TuT2, TuT3, TuT4, TTT1, Bg12, Bg16 and Bg18 (tetranucleotide repeats; Segelbacher et al. 2000; Caizergues et al. 2001; Piertney \& Höglund 2001). Afterwards, unique genotypes were molecularly sexed. Namely, we amplified 2 sex-specific markers: PU and P8mod (Pérez et al. 2011). Molecular sexing is based on the detection of the chromosomespecific difference in intron size in the CHD gene. We tested the reliability of molecular sexing using black grouse and capercaillie individuals of known sex from breeding facilities. We amplified two multiplex regions from the microsatellite loci, as described in Rutkowski et al. (2017b), whereas sex markers were amplified as described in Pérez et al. (2011). We used CEQ 8000 sequencer (BECKMAN COULTER) for the genotyping analyses. In the case of microsatellites we used precautions to avoid genotyping errors following the protocol described in Rutkowski et al. (2017b). Additionally, each sample was genetically sexed in five independent repetitions.

\section{Statistical analysis}

The analyses of the microsatellite genotyping were carried out in several stages. First, we identified the samples with the same genotype and, assuming that these samples originated from the same individuals, determined the number of unique genotypes in the studied population. Then, for all unique genotypes, we determined the sex and calculated the Probability of Identity (P(ID), average probability that two randomly sampled unrelated individuals from the same population will have the same genotype) for each locus within each population, as well as for a combination of nine loci. We conducted the analysis using GenAlEx v. 6.501 (Peakall \& Smouse 2012).

\section{RESULTS}

We successfully genotyped 193 samples (73\% of all samples collected): 104 from black grouse $(\approx 63 \%)$, and 89 from capercaillie $(89 \%)$. We obtained 44 unique genotypes for the black grouse and 33 for the capercaillie. The P(ID) for the combination of 8 loci was $2.1 \cdot 10^{-7}$ for the black grouse and $2 \times 10^{-6}$ for the capercaillie

In birds, males are homogametic (sex chromosomes $\mathrm{ZZ}$ ) and females heterogametic (ZW), thus we classified an individual as male when only a single fragment was amplified in the PCR 
reaction (exhibited as a single 'peak' in chromatograme) or as a female when two fragments were amplified (exhibited as the two 'peaks'). We found a sex-ratio of 1:15 for the capercaille ( 2 females, 31 males) and a sex-ratio of 1:6 for the black grouse ( 6 females, 38 males). Multiple repetitions of samples indicated low sexing error. Combination of results from different samples of single individual, revealed by microsatellite genotyping, and repetition of genetic sexing for the particular unique genotype indicated sexing error in less than $10 \%$ of cases.

\section{DISCUSSION}

The results show a clear deviation from an equal sex ratio with bias towards males in both species, particularly in the capercaillie. There are three possible reasons for such significant differences in the identified number of individuals of both sexes: disturbance in the population demography associated with declining numbers; collection of non-invasive material mainly from cocks due to a varied activity of individuals of both sexes; technical problems resulting from the poor quality of genetic material obtained from non-invasive samples.

Many species of grouse (Galliformes) including the capercaillie and the black grouse, are threatened with extinction, mainly due to the progressive fragmentation of the forest habitat (Caizergues et al. 2003, Brickle et al. 2008, Segelbacher et al. 2008). Among grouse, the sex ratio depends on many factors, and a biased ratio towards one of the sexes is often reported. The differences in the number of individuals of one sex might occur at the level of the breeding cohort and of the entire population (Hörnfeldt et al. 2001, Donald 2007, Kidwai et al. 2011, Wilkinson et al. 2018). In poorer habitats, birds with sexual dimorphism, where males are larger than females, produce more female offspring due to higher mortality of male offspring, which usually need more food to grow faster (Lindén 1981, Moss \& Oswald 1985, Moss et al. 2008). In good quality habitats, the sex ratio is usually equal (Ellison \& Magnani 1985, Marti et al. 2016). Differences in sex ratios can also be caused by a difference in the predation pressure. Females often lead a secretive lifestyle and have mimetic colorations, whereas the more active and larger males are more vulnerable to attacks, especially during the mating season. Conversely, brooding females are more vulnerable to attacks, e.g by foxes, as their ability to escape is limited (CluttonBrock 1986, Clutton-Brock \& Vincent 1991). At least in the case of the capercaillie, evidence suggests a system where females are more intensively eliminated from the population. In studies on the reintroduced population in the Lower Silesian Forest, higher survival rates of cocks released into a new environment were observed (Merta et al. 2013). The predominance of males in the population often occurs in small and declining populations is also observed in other birds, e.g. in the willow warbler (Phylloscopus trochilus ) (Morrison et. al. 2016). In the case of game birds, including grouses, hunting is an additional factor that might affect the sex ratio in a population (Zbinden et al. 2018).

The high number of identified males may also be related to the timing of collection of the biological material. The non-invasive samples were collected from February to May, during the snow cover period, when tracks and droppings are easier to spot. This period also corresponds to the mating season of the capercaillie and the black grouse, thus finding male traces in the vicinity of lekking sites is a much easier task. In this period males are very active (Storch 1995, Lindström et. al. 1998), whereas hens lead a secretive lifestyle and are more prone to intrapopulation migration (Storch \& Segelbacher 2000, Corrales \& Höglund 2012, Rutkowski et al. 2013). Females on the other hand, visit small lek areas less frequently. With the decline in the number and fragmentation of the population, single cocks appear in lek areas. This results in a decrease in the activity of females, and thus they do not leave "traces" in the lek (Alatalo et. al 1992). This regularity is also observed in other groups of birds (Durães et al. 2009). Moreover, for other lekking species (e.g. manakins) it was shown that females only stay in the lek for short 
periods, visit numerous lekking sites, have larger home ranges and are thus significantly less bound to the lekking sites as compared to males. Males rarely leave lekking sites, usually only very briefly to feed. It may intensify the effect of uneven probability of sex detection, as the biological traces of the presence of females are dispersed (Théry 1992).

Another reason for such a visible deviation in the sex ratio may be errors resulting from the use of non-invasive samples, such as droppings, as a source of genetic material for sex identification (Bonin et al. 2004, Johnson \& Haydon 2007). Apart from the possibility of False Alleles (FA) appearing as the results of samples' contamination, a serious technical problem is also Allelic Drop-out (ADO), i.e. the lack of amplification of one of the microsatellite alleles, especially the longer one (Taberlet et al. 1999, Broquet \& Petit 2004). This might result in the heterozygous genotypes to actually be identified as homozygous. The identification method we used was based on identifying homo- and heterozygous individuals, with heterozygosity interpreted as evidence that the focal individual is a female, meaning that ADO could have caused an underestimation of real number of females. In other instances this methods did not cause such biases (the capercaillie non-invasive analysis in the Gorce National Park, unpublished data) and although we employed several measure to prevent identification errors (e.g. multitube strategy) we cannot rule out that some of the genotypes were mistakenly identified as males.

In summary, despite intensive sampling, the observed biased sex ratio may differ from the actual value as sample collection method might have resulted in a higher number of identified cocks. Laboratory errors, even if it occurs, were insignificant due to the procedures used and the scale of obtaining biological material (over 260 samples from both species in total). This leads to the assumption that in the population of the capercaillie and black grouse in the Tatra National Park there is some deviation from the equal sex ratio, biased towards males.

\section{ACKNOWLEDGEMENTS}

We thank Aleksandra Gwiazdowska for help with DNA isolation and the reviewers for their constructive comments on the text. The research was financed from the forest fund under the agreement concluded between the State Forests National Forest Holding and the Tatra National Park in 2019 (grant no EZ.0290.1.18.2019/21,22).

\section{REFERENCES}

Alatalo R. V., Höglund J., LundBerg A. \& Sutherland W. J. 1992. Evolution of black grouse leks: female preferences benefit males in larger leks. Behavioral Ecology 3 (1): 53-59. DOI: https://doi.org/10.1093/beheco/3.1.53

Baumgardt J. A., Goldberg C. S., Reese K. P., Connelly J. W., Musil D. D., Garton E. O. \& Waits L. P. A. 2013. Method for estimating sex ratio for sage-grouse using noninvasive genetic samples. Molecular Ecology Resources 13:393-402. DOI: https://doi.org/10.1111/1755-0998.12069

Beja-Pereira A., Oliveira R., Alves P.C., Schwartz M. K. \& Luikart G. 2009. Advancing ecological understandings through technological transformations in noninvasive genetics. Molecular Ecology Resources 9: 1279-1301. DOI: 10.1111/j.1755-0998.2009.02699.x

BESSA-GOMES C. S., LEGENDRE S. \& CLOBERT J. 2004. Allee effects, mating systems and the extinction risk in populations with two sexes. Ecology Letters 7: 802-812. DOI: https://doi.org/10.1111/j.1461-0248.2004.00632.x

Blackmore C. J., Peakall R. \& Heinsohn R. 2011. The absence of sex-biased dispersal in the cooperatively breeding grey-crowned babbler. Journal of Animal Ecology 80(1): 69-78. DOI: https://doi.org/10.1111/j.13652656.2010.01761.x

Bonin A., Bellemain E., Bronken Eidesen P., Pompanon F., Brochmann C. \& Taberlet P. 2004. How to track and assess genotyping errors in population genetics studies. Molecular Ecology 13: 3261-3273. DOI: 10.1111/j.1365-294X.2004.02346.X

Brickle N. W., Duckworth J. W., Tordoff A. W., Poole C. M., Timmins R. \& Mcgowan P. J. 2008. The status and conservation of Galliformes in Cambodia, Laos and Vietnam. Biodiversity and Conservation. 17(6): 13931427. DOI: $10.1007 / \mathrm{s} 10531-008-9346-\mathrm{z}$

BroqueT T., \& PETIT E. 2004. Quantifying genotyping errors in noninva-sive population genetics. Molecular Ecology 13:3601-3608. DOI: 10.1111/j.1365-294X.2004.02352.x 
Broquet T., Menard N. \& Petit E. 2007. Noninvasive population genetics: a review of sample source, diet, fragment length and microsatellite motif effects on amplification success and genotyping error rates. Conservation Genetics 8: 249-260. DOI: 10.1007/s10592-006-9146-5

Bush K. L., Vinsky M. D., Aldridge C. L., \& PAszKowski C. A. 2005. A comparison of sample types varying in invasiveness for use in DNA sex determination in an endangered population of greater Sage-Grouse (Centrocercus uropihasianus). Conservation Genetics 6(5): 867-870. DOI: 10.1007/s10592-005-9040-6

Caizergues A., Dubois S., Mondor G. \& Rasplus J.F. 2001. Isolation and characterisation of microsatellite loci in black grouse (Tetrao tetrix). Molecular Ecology Notes 1 (1-2): 36-38. DOI: 10.1046/j.1471-8278.2000.00015.x

Caizergues A., RÄtti O., Helle P., Rotelli L., Ellison L. \& Rasplus J. Y. 2003. Population genetic structure of male black grouse (Tetrao tetrix L.) in fragmented vs. continuous landscapes. Molecular Ecology. 12 (9): $2297-$ 2305. DOI: 10.1046/j.1365-294x.2003.01903.x

Ciach M. 2016. Cietrzew Tetrao tetrix. Pp. 135-142. In: Wilk T., Bobrek R., PęPKowska-Król A., Neubauer G., KosicKi J. Z. (eds), Ptaki polskich Karpat - stan, zagrożenia, ochrona. OTOP: Marki, Poland.

Clout M. N., Elliott G. P. \& Robertson B. C. 2002. Effects of supplementary feeding on the offspring sex ratio of kakapo: a dilemma for the conservation of apolygynous parrot. Biological Conservation 107: 13-18. DOI: 10.1016/S0006-3207(01)00267-1

CoRRALES C. \& HöGLUND J. 2012. Maintenance of gene flow by female-biased dispersal of Black Grouse Tetrao tetrix in northern Sweden. Journal of Ornithology 153(4): 1127-1139. DOI: 10.1007/s10336-012-0844-0

Clutton-Brock T. H. 1986. Sex ratio variation in birds. Ibis 128: 317-329. DOI: https://doi.org/10.1111/j.1474919X.1986.tb02682.x

Clutton-Brock T. H \& Vincent A. C. J. 1991. Sexual selection and the potential reproductive rates of males and females. Nature 351:58-60. DOI: 10.1038/351058a0

DONALD P. 2007. Adult sex ratios in wild bird populations. Ibis 149: 671-692. DOI: 10.1111/j.1474-919X.2007.00724.x

Dubiec A. \& ZAGALSKA-Neubauer M. 2006. Molecular techniques for sex identification in birds. Biological Letters. 43(1): 3-12.

Durães R., Loiselle B. A., Parker P. G. \& Blake J. G. 2009. Female Mate Choice Across Spatial Scales: Influence of Lek and Male Attributes on Mating Success of Blue-Crowned Manakins. Proceedings of the Royal Society B: Biological Sciences 276 (1663): 1875-1881. DOI:10.1098/rspb.2008.1752

EgGert L. S., EgGert J. A. \& WoOdRufF D. S. 2003. Estimating population sizes for elusive animals: the forest elephants of Kakum National Park, Ghana. Molecular ecology 12 (6): 1389-1402. DOI: 10.1046/j.1365294X.2003.01822.x

ELLEGREN H. \& SHELDON B. 1997. New tools for sex identification and the study of sex allocation in birds. Trends in Ecology \& Evolution 12:255-259. DOI: 10.1016/s0169-5347(97)01061-6

ELLISON L. N. \& MAGNANi Y. 1985. Eléments de dynamique de population du Tétras lyre (Tetrao tetrix) dans les Alpes Françaises. - Gibier Faune Sauvage. Game \& Wildlife Science 2: 63-84.

FISHER R. 1930. Genetical theory of sex allocation. Clarendon Press. London

Fontanesi L., Tazzoli M., Pecchioli E., Hauffe H. C., Robinson T. J. \& Russo V. 2008. Sexing European rabbits (Oryctolagus cuniculus), European brown hares (Lepus europaeus) and mountain hares (Lepus timidus) with ZFX and ZFY loci. Molecular Ecology Resources 8(6): 1294-1296. DOI: https://doi.org/10.1111/j.17550998.2008.02167.x

HARDY I. C. W. 2002. Sex Ratios: Concepts and Research Methods. Cambridge University Press. Cambridge.

Helle P., KuRKi S. \& LindEN H. 1999. Change in the sex ratio of the Finnish capercaillie Tetrao urogallus population. Wildlife Biology 5: 25-31. DOI: https://doi.org/10.2981/wlb.1999.005

Hori T., ASAKAWA S., ITOH Y., ShimizU N. \& MizUnO S. 2000. WPKCI, encoding an altered form of PKCI, is conserved widely on the avian W chromosome and expressed in early female embryos. Molecular Biology of the Cell 11:36453660. DOI: $10.1091 / \mathrm{mbc} .11 .10 .3645$

HÖRNFELDT B., HIPKISS T. \& EKLUND U. 2001. Juvenile sex ratio in relation to breeding success in capercaillie Tetrao urogallus and black grouse T. tetrix. Ibis 143: 627-631. DOI: 10.1111/j.1474-919X.2001.tb04890.x

JOHNSON P. C. \& HAYDON D. T. 2007. Maximum-likelihood estimation of allelic dropout and false allele error rates from microsatellite genotypes in the absence of reference data. Genetics 175 (2): 827-842. DOI: 10.1534/genetics.106.064618

KiDWAi Z., SANKAR K., Quershi Q. \& KHAN J. A. 2011. Abundance and habitat utilisation by Galliformes in the Sariska Tiger Reserve, Rajasthan, India. International Journal of Galliformes Conservation 2: 54-60.

Lambertucci S. A., Carrete M., Speziale K. L., Hiraldo F. \& Donázar J. A. 2013. Population sex ratios: another consideration in the reintroduction-reinforcement debate? PloS One 8: e75821. DOI: 10.1371/journal.pone.0075821

LeE A. M., SÆTher B.-E. \& Engen S. 2011. Demographic Stochasticity, Allee Effects, and Extinction: The Influence of Mating System and Sex Ratio. The American Naturalist 177(3): 301-313. DOI: 10.1086/658344

LINDÉN H. 1981. Estimation of juvenile mortality in capercaillie Tetrao urogallus and the black grouse, Tetrao tetrix from indirect evidence. Finnish Game Research 39: 35-51.

LiNDSTRÖM J., RINTAMÄKI P.T. \& STORCH I. 1998. Black grouse-BWP update. The journal of birds of the Western Palearctic. Oxford University Press, Oxford 2:173-191. 
MARti C., Bossert A. \& PAUli H. R .2016. Population trend of Black Grouse Tetrao tetrix and Rock Ptarmigan Lagopus muta in the Aletsch region (central Alps, Switzerland) from 1970 to 2015. Der Ornithologische Beobachter 113: 1 -30 .

Merta D., Kobielski J., KRZYwinski A. \& RzońCA Z. 2013. Czynna ochrona głuszca Tetrao urogallus na terenie Borów Dolnośląskich. Studia i Materiały Centrum Edukacji Przyrodniczo-Leśnej 15: 195-209.

Morrison C. A., Robinson R. A., ClARK J. A. \& GILl J. A. 2016. Causes and consequences of spatial variation in sex ratios in a declining bird species. Journal of Animal Ecology 85: 1298-1306. DOI: 10.1111/1365-2656.12556

Moss R. \& OSWALD J. 1985. Population dynamics of Capercaillie in a North-east Scottish glen. Ornis Scandinavica 16(3): 229-238. DOI: $10.2307 / 3676635$

Moss R., Picozzi N., Summers R. W. \& Baines D. 2008. Capercaillie Tetrao urogallus in Scotland - demography of a declining population. Ibis 142(2): 259-267. DOI: 10.1111/j.1474-919X.2000.tb04865.x

NAVARA K. J. 2018a. Introduction to Vertebrate Sex Ratio Adjustment. In: Choosing Sexes. Fascinating Life Sciences. Cham, Switzerland: Springer.

NAVARA K. J. 2018b. The Bees Do It, but What About the Birds? Evidence for Sex Ratio Adjustment in Birds. In: Choosing Sexes. Fascinating Life Sciences. Cham, Switzerland: Springer.

PeAKall R. \& Smouse P. E. 2012. GenAlEx 6.5: genetic analysis in Excel. Population genetic software for teaching and research-an update. Bioinformatics Applications Note 28: 2537-2539.

PÉREZ T., VÁZQUEZ J. F., QUIRós F. \& DOMÍNGUEZ A. 2011. Improving non-invasive genotyping in capercaillie (Tetrao urogallus): redesigning sexing and microsatellite primers to increase efficiency on faeces samples. Conservation Genetics Resources 3(3): 483-487. DOI: 10.1007/s12686-011-9385-8

PIERTNEY S. B. \& HöGLUND J. 2001. Polymorphic microsatellite DNA markers in black grouse (Tetrao tetrix). Molecular Ecology Notes 1(4): 303-304. DOI: 10.1046/j.1471-8278

Piggott M. P., Bellemain E., TABerlet P. \& TAYloR A.C. 2004. A multiplex pre-amplification method that significantly improves microsatellite amplification and error rates for faecal DNA in limiting conditions. Conservation Genetics 5(3): 417-420. DOI: 10.1023/B:COGE.0000031138.67958.44

PRYKE S. R. \& ROLLINS L.A. 2012. Mothers adjust offspring sex to match the quality of the rearing environment. Proceedings of the Royal Society B: Biological Sciences 279(1744): 4051-7. DOI: 10.1098/rspb.2012.1351

REgNAUT S., LuCAS F. S. \& FuMAGALli L. 2006. DNA degradation in avian faecal samples and feasibility of noninvasive genetic studies of threatened capercaillie populations. Conservation Genetics 7 (3): 449-453. DOI: 10.1007/s10592-005-9023-7

Robertson B. C., Elliott G. P., EAson D. K., Clout M. N. \& Gemmell N. J. 2006. Sex allocation theory aids species conservation. Biology Letters 2(2): 229-231. DOI: 10.1098/rsbl.2005.0430

RUTKOWSKI R., SUCHECKA E. \& ZAWADZKA D. 2013. Migracyjność zależna od płci a genetyczna struktura populacji kuraków leśnych. Postępy Techniki w Leśnictwie. 122: 28-33.

RutKowski R., Dulisz B., SzcZEPAŃSKi S., NowAKOwsKi J. J., ZwiJACZ-KozicA T. \& KrZAn P. 2017a. Conservation genetics of the capercaillie in Poland - estimating the size of the Tatra National Park population by the genotyping of non-invasive samples. Fragmenta Faunistica 60(2): 119-128. DOI: 10.3161/00159301FF2017.60.2.119

RutKowski R., ZAWAdZKa D., Suchecka E. \& MERTA D. 2017b. Conservation genetics of the capercaillie in PolandDelineation of conservation units. PLoS One 12(4): p.e0174901. DOI: 10.1371/journal.pone.0174901

SANTOREK A., KULIGOWSKA B., SZCZEPAŃSKi S., DUlisZ B. \& RUTKOWSKI R. 2018. Ocena liczebności głuszca (Tetrao urogallus) w Babiogórskim Parku Narodowym na podstawie analiz genetycznych prób nieinwazyjnych. Studia i Materiały Centrum Edukacji Przyrodniczo-Leśnej w Rogowie 54 (4): 125-133.

Segelbacher G., PAXTON R.J., SteinbruCK G., TrontelJ P. \& STORCh I. 2000. Characterization of microsatellites in capercaillie Tetrao urogallus (Aves). Molecular Ecology 9(11): 1934-1935. DOI: 10.1046/j.1365294x.2000.0090111934.x

SEgElbacher G. \& Steinbrück G. 2001. Bird faeces for sex identification and microsatellite analysis. Vogelwarte 41:139-142

Segelbacher G., Manel S. \& Tomiuk J. 2008. Temporal and spatial analyses disclose consequences of habitat fragmentation on the genetic diversity in capercaillie (Tetrao urogallus). Molecular Ecology 17 (10): 2356-2367. DOI: 10.1111/j.1365-294X.2008.03767.x

STORCH I. 1995. Annual home ranges and spacing patterns of capercaillie in central Europe. The Journal of Wildlife Management 59: 392-400. DOI: https://doi.org/10.2307/3808953

StORCH I. \& SEgElbaCher G. 2000. Genetic correlates of spatial population structure in central European capercaillie Tetrao urogallus and black grouse T. tetrix: a project in progress. Wildlife Biology 6:305-310. DOI: 10.2981/wlb.2000.014

StORCH I. (ed.). 2007. Grouse - Status Survey and Action Plan 2006-2010. IUCN. Gland Switzerland and Cambridge UK and World Pheasant Association, Fordinbridge, UK.

Sun Y. H., Swenson J. E., FAnG Y., KLAus S. \& Scherzinger W. 2003. Population ecology of the Chinese grouse, Bonasa sewerzowi, in a fragmented landscape. Biological Conservation 110 (2): 177-184. DOI: 10.1016/S00063207(02)00187-8 
TABerlet P., Waits L. P. \& Luikart G. 1999. Noninvasive genetic sampling: look before you leap. Trends in Ecology \& Evolution 14: 323-327. DOI: 10.1016/s0169-5347(99)01637-7

THÉRY M. 1992. The evolution of leks through female choice: differential clustering and space utilization in six sympatric manakins. Behavioral Ecology and Sociobiology 30 (3): 227-237. DOI: 10.1007/BF00166707

TRIVERS R. L. \& WiLlaRd D. E. 1973. Natural Selection of Parental Ability to Vary the Sex Ratio of Offspring. Science 179(4068): 90-92. DOI: 10.1126/science.179.4068.90

Vanderkist B. A., Xue X. H., Griffiths R., Martin K., Beauchamp W. \& Williams T. D. 1999. Evidence of malebias in capture samples of Marbled Murrelets from genetic studies in British Columbia. The Condor 101: 398 -402. DOI: https://doi.org/10.2307/1370004

WAITS L.P. \& PAETKAU D. 2005. Noninvasive genetic sampling tools for wildlife biologists: a review of applications and recommendations for accurate data collection. Journal of Wildlife Management 69(4): 1419-1433. DOI: 10.2193/0022-541X(2005)69[1419:NGSTFW]2.0.CO;2

WEST S.A. 2002. Constraints in the Evolution of Sex Ratio Adjustment. Science 295 (5560): 1685-1688. DOI: $10.1126 /$ science. 1069043

West S. 2009. Sex Allocation. Princeton University Press. Princeton. NJ.

Wilkinson N. I., EATON M. A., Marshall G. \& Haysom S. 2018. The population status of Capercaillie Tetrao urogallus in Scotland during winter 2015-16. Bird Study 65(1): 1-16. DOI: 10.1080/00063657.2018.1439448

YAMASHIRO A., KANESHIRO Y., KAWAGUCHI Y. \& YAMASHIRO T. 2017. Species, sex, and individual identification of Japanese serow (Capricornis crispus) and sika deer (Cervus nippon) in sympatric region based on the fecal DNA samples. Conservation Genetics Resources 9(2): 333-338. DOI: 10.1007/s12686-016-0665-1

Zbinden N., SAlvioni M., KoRner-NiEvergelt F. \& Keller V. 2018. Evidence for an additive effect of hunting mortality in an alpine black grouse Lyrurus tetrix population. Wildlife Biology 2018(1): wlb.00418. DOI: 10.2981/wlb.00418.

\section{STRESZCZENIE}

[Molekularna identyfikacja płci wykonana na podstawie nieinwazyjnych prób sugeruje zaburzoną proporcję płci w populacji głuszca i cietrzewia w Tatrzańskim Parku Narodowym]

Proporcja płci (stosunek liczby samców do liczby samic) jest znaczącym czynnikiem wpływającym na prawdopodobieństwo przetrwania populacji. Zaburzona proporcja płci może przyczyniać się niekorzystnych procesów demograficznych, szczególnie w przypadku gatunków zagrożonych. Analiza DNA pozyskiwanego z prób nieinwazyjnych jest efektywnym sposobem monitorowania zwierząt rzadkich bądź trudnych w obserwacji. Taką metodę wykorzystano $\mathrm{w}$ celu określenia proporcji płci w populacji głuszca (Tetrao urogallus) i cietrzewia (Lyrurus tetrix) w Tatrzańskim Parku Narodowym. Zebrano ponad 250 prób (gównie odchodów), a następnie przeprowadzono identyfikację osobniczą (genotypowanie mikrosatelitarne) i określono płeć (różnice wielkości intronów genu CHD, sprzężonego z płcią) dla każdego unikatowego genotypu. Analizy genetyczne wykazały, że większość zebranego materiału pochodziła od samców. Odchylenie od równej proporcji płci było bardzo wyraźne. To sugeruje, że w badanej populacji głuszca i cietrzewia jest o wiele więcej kogutów niż kur. Jednakże wyniki należy interpretować ostrożnie, ponieważ na stwierdzone odchylenie wpływ mógł mieć także sposób pozyskiwania materiału w terenie - koguty są o wiele aktywniejsze, w związku z czym o wiele łatwiej trafić na ich tropy oraz ślady biologiczne. Uzyskane wyniki wskazują na potrzebę dalszego monitorowania proporcji płci tych gatunków w Tatrzańskim Parku Narodowym, w oparciu zarówno o metody genetyczne jak i obserwacje. 